\title{
PEMBELAJARAN KONTEKSTUAL DALAM MEWUJUDKAN MERDEKA BELAJAR
}

\author{
Eko Suhartoyo', Sitti Ainun Wailissa ${ }^{2}$, Saika Jalarwati1, Samsia ${ }^{3}$, Surya Wati', Nur \\ Qomariah", Elly Dayanti', Imas Maulani' ${ }^{4}$ Imam Mukhlish', Muhammad Holqi Rizki \\ Azhari $^{3}$, Hidayatulloh Muhammad Isa', Ilham Maulana Amin ${ }^{3}$ \\ ${ }^{1}$ Fakultas Keguruan dan Ilmu Pendidikan, Universitas Islam Malang \\ ${ }^{2}$ Fakultas Teknik, Universitas Islam Malang \\ ${ }^{3}$ Fakultas Agama Islam, Universitas Islam Malang \\ ${ }^{4}$ Fakultas Ekonomi dan Bisnis, Universitas Islam Malang \\ Korespondensi email: suhartoyoeko@unisma.ac.id
}

\begin{abstract}
ABSTRAK
Gagasan merdeka belajar yang disampaikan oleh Mendikbud bahwa salah satunya adalah pembelajaran itu harus menyenangkan, tidak membuat peserta didik merasa tertekan, peserta didik bebas memilih arah kreatifitas mereka sendiri. Adapun peran seorang guru tidak lagi menjadi satu satunya sumber belajar, sebaliknya seorang guru yang dapat membantu peserta didik menemukan bakat mereka sendiri. Desa Sukorejo masih banyak memiliki lingkungan yang pure belum banyak diubah oleh teknologi, kemerdekaan belajar dapat diwujudkan melalui pembeljaran kontekstual learning dengan cara guru menggunakan pendekatan humanis. Peserta didik di berikan materi yang hubungannya dekat dengan lingkungan mereka. Kemerdekaan belajar memang seharusnya diterapka dilingkungan belajar peserta didik, karena hal ini sangat menentukan output sekolah, terlebih jika peserta didik dipandang sebagai insan kamil, bukan sebauh robot yang harus memenuhi perintah tuannya sama persis $100 \%$.
\end{abstract}

Kata Kunci: pembelajaran kontekstual; merdeka belajar.

\section{PENDAHULUAN}

Belakangan, program "Merdeka Belajar" yang digagas Kementerian Pendidikan dan Kebudayaan (Kemendikbud) diperhatikan banyak kalangan. Kemendikbud menyebutkan di website-nya bahwa program itu berhubungan dengan (a) Ujian Berstandar Nasional (USBN), (b) Ujian Nasional (UN), (c) Rencana Pelaksanaan Pembelajaran (RPP), dan (d) Peraturan Penerimaan Peserta Didik Baru (PPDB) Zonasi (Pratama, 2020) (Mustaghfiroh, 2020).

Empat perubahan di atas tentu digagas demi menunjang "kemerdekaan belajar". Perubahan terhadap ujian (USBN dan UN) dilakukan demi memperbaiki mutu lulusan, sekaligus memerdekakan siswa dari berbagai aktivitas belajar yang tak perlu dilakukan. Perombakan RPP yang dibuat guru dilakukan untuk efisiensi dan memerdekakan guru dari segala administrasi pembelajaran yang tidak benar-benar diperlukan. Dan, perubahan pada PPDB Zonasi dilakukan agar penerimaan siswa di sekolah-sekolah bisa dilaksanakan lebih fleksibel. (Pratamsa 2020)

Sekolah Dasar (SD) sebagai salah satu lembaga pendidikan formaldanberjenjang pada tingkat pendidikan dasar, cukup strategis dalam mewujudkanamanat pemerintah di bidang pendidikan. Pelaksanaan aspirasi tersebut tertuangdalam pasal 3 Peraturan 
Pemerintah Nomor 28 tahun 1990 tentang Pendidikan Dasar yang menyatakan bahwa, Pendidikan Dasar bertujuan memberi bekal kemampuan dasar kepada siswa untuk mengembangkan kehidupan sebagai pribadi,anggota masyarakat, warga negara, dan anggota umat manusia serta mempersiapkansiswa untuk mengikuti pendidikan menengah (Wahyuningsih et al., 2011) (Maryam et al., 2014).

Kegiatan belajar mengajar adalah suatu kegiatan yang bernilai edukatif yang diwarnai dengan interaksi yang terjadi antara guru dengan siswa untuk mencapai tujuan kegiatan belajar mengajar (Inah, 2015) (Hasan et al., 2020). Tercapainya tujuan dalam belajar mengajar merupakan harapan yang selalu dituntut pada guru dan ini merupakan masalah yang dirasa cukup sulit karena siswa merupakan individu dengan berbagai keunikan dan makhluk sosial dengan latar belakang yang berbeda-beda. Perbedaan tersebut antara lain dalam hal: intelektual, psikologis, dan biologis (Widyaningsih \& Rosidi, 2015) (Kurniasih et al., 2019).

Proses pembelajaran selama ini di sekolah terutama sekolah dasar lebih sering dilakukan secara pasif, artinya guru menjelaskan materi dan peserta didik mendengarkan. Padahal pendekatan belajar aktif telah dirintis secara serius oleh Balitbang Depdiknas sejak tahun 1979 dengan proyek yang dikenal sebagai Proyek Supevisi dan CBSA (Cara Belajar Siswa Aktif) (Ulia et al., 2019). Hasilnya kemudian direplikasikan di sejumlah daerah dimulai pada tingkat sekolah dasar sehingga secara bertahap diintergrasikan ke dalam Kurikulum 1984, Kurikulum 1994, KBK 2004 dan KTSP 2006). Kenyataan yang terjadi pada saat penerapan di lapangan. (Toyiba, Fitriyani, 2016).

Pembelajaran dikelas yang cendrung pasif membuat peserta didik mudah jenuh dan menurunkan minta peseta didik dalam memahami pelajaran (Khoirunnisa et al., 2020). Maka gagasan yang dikeluarkan oleh Mendikdud Nadiem Makarim menekankan pada pembelajaran menyenangkan, yang melibatkan partisifasi peserta didik lebih banyak ketimbang guru, pembelajaran seperti ini oleh Mendikbut Nadiem Makarim memberikan istilah Kemerdekaan Belajar.

Di SDN 1 Sukorejo masih banya memiliki kawasan perkebunan yang ditumbuhi berbabgai jenis tanaman, dan memiliki fungsi yang baik untuk kesehatan (tanaman obat), hal ini memberikan simbiosis mutualisme, guru akan mudah menerapkan metode pembelajaran kontekstual learning sebagai wujud dari kemerdekaan belajar. namun berdasarkan fakta yang ada guru di SDN 1 Sukorejo masih minim memanfaatkan lingkungan disekeliling sebagai sekolah untuk media ataupun objek materi.

Model pembelajaran kontekstual (contekstual teaching and learning) adalah merupakan proses pembelajaran yang holistik dan bertujuan membantu siswa untuk memahami makna materi ajar dan mengaitkannya dengan konteks kehidupan mereka sehari-hari (konteks pribadi, sosial dan kultural), sehingga siswa memiliki pengetahuan/ keterampilan yang dinamis dan fleksibel untuk mengkonstruksi sendiri secara aktif pemahamannya (Hasibuan \& Pd, 2014).

\section{METODE}

Pihak yang terlibat dalam mengaplikasi metode kontekstual learning dalam mewujudkan kemerdekaan belajar yaitu dari guru, peserta didik, orangtua an masyarakat. Metode pengajaran yang digunakan adalah dengan inkuri dengan melibatkan peserta didik kelas 1,2,3,4 SDN 1 Sukorejo dalam pelatihan dokter kecil sebagai upaya untuk memberikan bkal kepada peserta didik sehingga mampu mandiri dalam memecahkan masalah-masalah kecil di lingkungannya, seperti: Peserta didik tahu bagaiman menjaga kondisi tubuh pada setiap pergantian musim. Urutan kegiatannya adalah sebagai berikut: 
1. Peserta didik diminta untuk membawa berbagai tanaman jenis obat, seperti jahe, lengkuas, kunyit dan lain-lain

2. Peserta didik diperkenalkan lebih detai mengenai tumbuhan yang mereka bawa berdasarkan manfaatnya.

3. Peserta didik diberikan simulasi bagaimana cara mengolah tanaman sehingga menjadi obat.

Tujuan dari pengabdian masyarakat ini adalah untuk meningkatkan minat serta kemandirian dalam bergaul ditengah kehidupan masyarakat peserta didik.

\section{HASIL DAN PEMBAHASAN}

Berdasarkan hasil kegiatan di lapangan peserta didik yang mengikuti pembelajaran dengan kontekstual learning yaitu lebih aktif dan komunikatif. Karena peserta didik langsung berintraksi dengan lama terbuka, maka peserta tidak perlu kesulitan mendeskripsikan materi di pikirannya.

Selain itu peserta didik juga aktif dan komunikatf, peserta secara tidak langung mengajari teman sejawatnya, serta saling menanyakan beberapa materi yang sulit. Pembelajaran konstul ini lebih berkesan di dalam kehidupan peserta didik.

Tingkat keaktifan peserta didik dilihat dari rasa ingin tahu yang tinggi terhadap suatu masalah. Karena didalam kegiatan dilapangan peserta didik juga diajarkan bagaimana merawat tanaman teserbut serta beberapa kendala yang menjadikan tanama tersebut tidak dapat tumbuh atau mati.

Kesulitan peserta didik SDN 1 Sukorejo dalam memahami materi di sebabkan karena pengembangan materi jauh dari contoh permasalahan dilingkungan peserta didik. Secara metode peserta didik akan lebih cepat memahami materi jika berikan sebuah contoh atau disebut dengan simulasi (metode pembelajaran simulasi). Selain memudahkan ingatan peserta didik juga lebih enteng ketimbang seorang guru banyak mencotohkan materi yang langsung diambil dari buku paket/LKS dll.

Dengan pembelajran kontekstual learning peserta didik bukan hanya memahami jalannya materi tetapi paham tujuan pembelajaran atau fungsi materi tersebut dilingkungannnya sehari-hari. Disamping memberikan nilai kognitif peserta didik yang berikan pembelajaran kontekstual learning maltih sikap mandiri, khusus di pelajaran ilmu pengetauhan alam. Beberapa tumbuhan didekitar lingkungan mereka mejadi objek pembelajaran yang menyenangkan. Karena banyak hal-hal baru yang bisa mereka tangkap ketimbang hanya memahami materi secara kognitif, dengan pembelajaran kontekstual learning peserta didik juga secara tidak lagsung mendapat nilai-nilai afektif seperti bisa belajara lebih mandiri dalam pembelajaran Ilmu Pengetauhan Alam, peserta didik diajarkan beberapa tanaman sekaligus fungsi tanaman tersebut sebagai TOGA (Tanaman Obat Keluarga).

\section{KESIMPULAN}

Pembelajaran Kontekstual Learning dalam mewujudkan kemerdekaan belajar, memberika kontribusi banyak dalam mengaktualisasi program Mendikbut. Efek yang berikan ke peserta didik juga sangat beragam yang berniali plus. Peserta didik mendapatkan nilai kognitif, afektif juga psikomotorik. Hal ini juga didukung oleh lingkungan SDN 1 Sukorejo yang masih pure atau belum banyak tersentuh oleh teknologi, banyak kekayaan alam di Sukorejo yang mudal diamati oleh peserta didik hanya dengan kelur kelas, tanpa harus masuk ke tengah kebun. 


\section{UCAPAN TERIMA KASIH}

Ucapan terima kasih kami sampaikan kepada beberapa pihak, diantaranya pertama, LPPM Universitas Islam Malang selaku pemberi tugas dalam kegiatan pengabdian kepada masyarakat. Kedua, kepada Pemerintah Kabupaten Malang selaku pemberi ijin atas kegiatan pengabdian kepada masyarakat di wilayah Kabupaten Malang, dan juga ucapan terima kasih kami sampaikan kepada Kepala Desa Sukorejo Kecamatan Tirtoyudo, yang telah bersedia menerima kami dalam melaksanakan kegiatan pengabdian kepada masyarakat.

\section{DAFTAR RUJUKAN}

Hasan, N., Setyowidodo, G., Wafa, M. S., Irfan, M., Riadi, S., Annafisah, K., Alfanny, M. I. R., Aprilia, I., Faizin, T. G., Rizkiyah, N., \& Qowim, A. N. M. (2020). Pemberdayaan santri melalui pembelajaran enjoyable learning dalam membentuk generasi seimbang dan spiritualitas intelektualitas di pondok pesantren. Jurnal Pembelajaran $\begin{array}{lll}\text { Pemberdayaan } \quad \text { Masyarakat } & \text { (JP2M), } & \text { 148-152. }\end{array}$ https://doi.org/10.33474/jp2m.v1i2.6582

Hasibuan, D. H. M. I., \& Pd, M. (2014). Model Pembelajaran CTL (Contextual Learning) Teaching and Learning). II(01), 1-12.

Inah, E. N. (2015). Peran Komunikasi Dalam Interaksi Guru dan Siswa. Jurnal Al-Ta'dib, 8(2), 150-167. https://doi.org/10.31332/atdb.v8i2.416

Khoirunnisa, F., Sabekti, A. W., \& Yulita, I. (2020). Pengembangan Kemampuan Menulis Ilmiah Berbantukan Manajemen Referensi Mendeley Bagi Guru-Guru SMA/Sederajat Di Kabupaten Bintan. Jurnal Inovasi Hasil Pengabdian Masyarakat (JIPEMAS), 3(1), 1-6. https://doi.org/10.33474/jipemas.v3i1.2697

Kurniasih, Rahmati, N. A., Umamah, A., \& Widowati, D. R. (2019). English Conversation Class (ECC) Untuk Menciptakan English Environment Di SMA Islam Nusantara (SMAINUS). Jurnal Inovasi Hasil Pengabdian Masyarakat (JIPEMAS), 2(2), 161-169. https://doi.org/10.33474/jipemas.v2i2.2571

Maryam, I. S., Djahir, Y., \& Fitriyanti. (2014). Pencarian Penilaian Terhadap Hasil Belajar Peserta. Jurnal Profit, 1(1), 41-47. https://doi.org/10.36706/jp.v1i1.5511

Mustaghfiroh, S. (2020). Konsep "Merdeka Belajar” Perspektif Aliran Progresivisme John Dewey. Jurnal Studi Guru Dan Pembelajaran, 3(1 SE-Articles), 141-147. https://doi.org/10.30605/jsgp.3.1.2020.248

Pratama, E. (2020). Merdeka Belajar dan ruu sisdiknas. 1-2.

Toyiba, Fitriyani, N. (2016). Pengaruh Strategi pembelajaran Aktif Terhadap hasil belajar pada Madrasah Ibtidaiyah. Pendidikan Guru Madrasah Ibtidaiyah, 1(2), 929-930.

Ulia, N., Ismiyanti, Y., \& Setiana, L. N. (2019). Meningkatkan Literasi Melalui Bahan Ajar Tematik Saintifik Berbasis Kearifan Lokal. Jurnal Inovasi Hasil Pengabdian Masyarakat (JIPEMAS), 2(2), 150-160. https://doi.org/10.33474/jipemas.v2i2.3402

Wahyuningsih, D., Harlita, \& Joko Ariyanto. (2011). Pengaruh Strategi Pembelajaran Aktif Mind Maps Terhadap Hasil Belajar Biologi Siswa Kelas XI IPA SMA Negeri 2 $\begin{array}{llll}\text { Karanganyar. } & \text { Pendidikan } & \text { Biologi, } & \text { 1-8. }\end{array}$ https://jurnal.uns.ac.id/bio/article/view/5470

Widyaningsih, S., \& Rosidi, I. (2015). Pengaruh Pembelajaran Aktif Terhadap Hasil Belajar Siswa Pada Materi Pokok Plantae. Jurnal Pena Sains, 2(2). 